\title{
The Bangladesh/Myanmar Case: Continuity and Novelty in the Law of Maritime Boundary Delimitation
}

\author{
Professor Robin Churchill ${ }^{*}$
}

\section{Keywords}

Bangladesh, Myanmar, India, International Tribunal for the Law of the Sea, UN

Convention on the Law of the Sea, maritime delimitation, outer continental

shelf, maritime boundaries, territorial sea boundaries, exclusive economic zones

\section{Introduction}

On 14 March 2012, the International Tribunal for the Law of the Sea (ITLOS) gave its judgment in the Dispute concerning Delimitation of the Maritime Boundary between Bangladesh and Myanmar in the Bay of Bengal (Bangladesh/Myanmar). ${ }^{1}$ Although this case is listed as No. 16 in the ITLOS List of Cases, it is only the second occasion on which the ITLOS has given a judgment on the merits of a dispute, the first being the Saiga (No. 2) case (decided in 1999), ${ }^{2}$ and the first time that the ITLOS has dealt with maritime boundary delimitation. The latter subject has, however, been a popular one for litigation before other

\footnotetext{
Professor of International Law, University of Dundee.

${ }^{1}$ Dispute concerning Delimitation of the Maritime Boundary between Bangladesh and Myanmar in the Bay of Bengal (Bangladesh/Myanmar), Judgment of 14 March 2012 (hereafter referred to simply as 'Judgment'), available on the website of the ITLOS at <http://www.itlos.org/filead $\mathrm{min} /$ itlos/documents/cases/case_no_16/1-C16_Judgment_14_02_2012.pdf> [last accessed 10 April 2012]. For early commentary on the case, see I. Papanicolopulu, 'From the North Sea to the Bay of Bengal: Maritime Delimitation at the International Tribunal for the Law of the Sea, EJIL: Talk!, 23 March 2012, available at <http://www.ejiltalk.org/from-the-northsea-to-the-bay-of-bengal-maritime-delimitation-at-the-international-tribunal-for-the-lawof-the-sea/ $>$ [last accessed 2 April 2012].

2 The other 14 cases in the ITLOS list have concerned either provisional measures (four cases) or the prompt release of vessels (nine cases), together with one substantive dispute (the Swordfish case) which was settled out of court.
} 
international tribunals: the International Court of Justice and arbitral tribunals have so far decided nearly 20 cases between them, and several more cases are currently pending.

In the Bangladesh/Myanmar case the ITLOS was asked to delimit three maritime boundaries between the two states: the territorial sea boundary; the single maritime boundary between the exclusive economic zones (EEZs) and continental shelves of the two states; and the boundary of the continental shelf beyond 200 miles from the parties' baselines. ${ }^{3}$ The judgment is notable for maintaining what appears now to be the settled case law of international courts and tribunals regarding delimitation of single maritime boundaries, and for being the first occasion on which an international court or tribunal has delimited a continental shelf boundary beyond 200 miles and considered the issue of "grey zones" (i.e. zones on one side of a maritime boundary that are beyond the 200-mile limit of the state on that side of the boundary but that are within 200 miles of the state on the other side of the boundary). This note discusses in turn each of the three boundaries delimited by the ITLOS and the grey zone issue. It begins by briefly setting out the background to the case.

\section{Background}

Bangladesh is located in the northeast corner of the Bay of Bengal. ${ }^{4}$ It has a markedly concave coastline-indeed, its two principal stretches of coast meet almost at right angles. Bangladesh therefore risks having the outer areas of its maritime zones cut off by its neighbours, India and Myanmar. Bangladesh began maritime boundary negotiations with India and Myanmar in the 1970s, but by 2009 it appeared that those negotiations were unlikely to lead to agreements on maritime boundaries in the near future. By that time an apparently pressing issue was the leasing by Bangladesh to US and Irish companies of three hydrocarbon-rich blocks in the Bay of Bengal, which in the view of India and Myanmar overlapped their maritime zones. The two states reportedly sent notices to the companies concerned advising them not to

\footnotetext{
${ }^{3}$ All references to "miles" in this note are to nautical miles.

${ }^{4}$ For fuller discussion of the background, see J. Bissinger, 'The Maritime Boundary Dispute between Bangladesh and Myanmar: Motivation, Potential Solutions, and Implications', (2010) 10 Asia Policy 103; and M. Shah Alam and A. Al Faruque, 'The Problem of Delimitation of Bangladesh's Maritime Boundaries with India and Myanmar: Prospects for a Solution', (2010) 25 International Journal of Marine and Coastal Law 405.
} 
explore those blocks. ${ }^{5}$ In the light of those developments, Bangladesh decided to resort to litigation in order to have definitive maritime boundaries with its neighbours established, utilising for this purpose the 1982 UN Convention on the Law of the Sea (UNCLOS), ${ }^{6}$ which enables party states to initiate unilaterally proceedings leading to a binding third-party settlement where disputes relating to the Convention cannot be settled through agreed means. Although all three states were parties to the Convention in 2009, none had made a declaration under Article 287 selecting a preferred means for the settlement of disputes. Thus, Bangladesh had no choice but to go for arbitration under Annex VII of UNCLOS. ${ }^{7}$ It instituted arbitral proceedings against India and Myanmar on 8 October 2009, in each case requesting the arbitral tribunal to delimit the territorial sea, EEZ and continental shelf boundaries between the two states concerned. On 4 November 2009, Myanmar proposed that the case between it and Bangladesh should be transferred to the ITLOS, and made a declaration under Article 287 accepting the jurisdiction of the ITLOS for this purpose. On 12 December, Bangladesh made a similar declaration, and the ITLOS thereby became the forum for the case. ${ }^{8}$ The case between Bangladesh and India, however, is continuing before an Annex VII arbitral tribunal. The latter has worked at a much slower pace than the ITLOS, so that by the end of 2011 the first round of written proceedings had not been concluded. Thus, the tribunal is unlikely to deliver its award before 2013/2014. However, when it does so, it will have the benefit of knowing what the ITLOS decided in the Bangladesh/Myanmar case.

\section{The territorial sea boundary}

The macro-geographical situation described above is not directly relevant to the territorial sea boundary, although (as will be seen) it was of great relevance to the delimitation of the single maritime boundary. For delimitation of the territorial sea boundary, it was the geography in the immediate vicinity of the terminus of the Bangladesh-Myanmar land border that was relevant. The last part of the land border between Bangladesh and Myanmar follows the Naaf

\footnotetext{
5 'Dhaka to Seek UN Tribunal', The Daily Star, 9 October 2009, available at <http://www. thedailystar.net/newDesign/news-details.php?nid=108950 > [last accessed 11 April 2012]. A further factor seems to have been a survey for hydrocarbons in 2008 undertaken under licence from Myanmar in an area claimed by Bangladesh: see Bissinger, supra note 4, at 109 .

${ }^{6} 1833$ UNTS 396.

7 Art. 287(3)-(5), UNCLOS.

${ }^{8}$ Judgment, paras. 3,4 and 47.
} 
River and terminates at its mouth. The mainland coasts of Bangladesh and Myanmar on either side of the mouth of the Naaf River are relatively straight. Lying off the mouth of the Naaf River and extending south-eastwards roughly parallel to, and some five or six miles out from, the coast of Myanmar is St. Martin's Island, which belongs to Bangladesh (see Map 1 below). The island is about five miles long, has an area of $8 \mathrm{~km}^{2}$ and a population of about 7,000.9

In considering the territorial sea boundary, the ITLOS had first to deal with Bangladesh's argument that the boundary had already been delimited in Agreed Minutes of 1974, signed by the two heads of delegation following their second round of negotiations over maritime boundaries. The ITLOS rejected this argument, holding that the Agreed Minutes were no more than a record of a conditional understanding. Furthermore, the Agreed Minutes were not intended to create legal obligations; the head of the Myanmar delegation did not have the authority to engage his State in accordance with Article 7 of the Vienna Convention on the Law of Treaties; and the Agreed Minutes had not been submitted to the procedure required by their respective constitutions for binding international agreements. ${ }^{10}$ The ITLOS also rejected Bangladesh's argument that there was a tacit or de facto agreement on the territorial sea boundary resulting from the consistent conduct of the parties over three decades, finding that there was no convincing evidence to this effect. ${ }^{11}$ Bangladesh's argument that Myanmar was estopped from denying that there was any territorial sea boundary other than that set out in the Agreed Minutes was also found unconvincing by the ITLOS. It was held that the conditions required for an estoppel in international law had not been met. ${ }^{12}$

In situations where, as was the case here, there is no agreement between the states concerned, Article 15 of UNCLOS provides that the territorial sea boundary is to be an equidistance line unless "it is necessary by reason of historic title or other special circumstances to delimit the territorial seas of the two States in a way which is at variance therewith". Neither Bangladesh nor Myanmar had suggested that it had a historic title to any of the waters concerned, but Myanmar argued that St. Martin's Island was a special circumstance, in particular that it would be on the "wrong side" of an equidistance line drawn between the mainland coasts of Bangladesh and Myanmar. The ITLOS rejected that argument, observing that while it was not unprecedented in the case law of international courts and tribunals for islands to be given less than full effect in the

\footnotetext{
9 Judgment, paras. 143-4 and 314.

${ }^{10}$ Judgment, paras. 92-8.

${ }^{11}$ Judgment, paras. 112-18.

12 Judgment, paras. 124-5.
} 
delimitation of the territorial sea, the islands subject to such treatment were usually "insignificant maritime features" ${ }^{13}$ St. Martin's Island, however, was a significant maritime feature by virtue of its size and population and the extent of the economic and other activities connected with it, and there were therefore no compelling reasons that would justify treating the island as a special circumstance or preventing it from being given full effect in drawing the territorial sea boundary. ${ }^{14}$ Accordingly, the ITLOS drew the boundary as an equidistance line, utilising as base points the base points used by the parties, which were the lowwater lines along their coasts. ${ }^{15}$ The boundary begins at the terminus of the land frontier in the mouth of the Naaf River, then proceeds south-westwards equidistant between the parties' mainland coasts for a short distance, before turning south-eastwards equidistant between the mainland coast of Myanmar and the coast of St. Martin's Island to a point 12 miles from both those coasts (see Map 1). According to Judges ad hoc Mensah and Oxman, this line is "essentially the same as that contemplated by" the parties in the 1974 Agreed Minutes. ${ }^{16}$

\section{The single maritime boundary}

Since the Greenland/Jan Mayen case (1993) ${ }_{1}^{17}$ international courts and tribunals have, with the exception of the Nicaragua/Honduras case $(2007)^{18}$ (where the geographical circumstances were highly exceptional), adopted a fairly consistent methodology in delimiting the single maritime boundary between the overlapping EEZs and continental shelves of opposite or adjacent states, known as the "equidistance/relevant circumstances" method. ${ }^{19}$ This involves a three-stage process. ${ }^{20}$ First, a court or tribunal constructs an equidistance line as the provi-

\footnotetext{
${ }^{13}$ Judgment, para. 151, referring to the ICJ's judgment in the Qatar/Bahrain case: Maritime Delimitation and Territorial Questions between Qatar and Bahrain (Qatar v Bahrain) (Merits), ICJ Reports 2001, p. 40, at 104, para. 219.

${ }^{14}$ Judgment, paras. 151-2.

${ }^{15}$ Judgment, paras. 154-6.

${ }^{16}$ Joint Declaration of Judges ad hoc Mensah and Oxman, para. 2.

${ }^{17}$ Case concerning Maritime Delimitation in the Area between Greenland and Jan Mayen (Denmarkv Norway), Judgment, ICJ Reports 1993, p. 38, at 61, para. 51.

${ }^{18}$ Case concerning Territorial and Maritime Dispute between Nicaragua and Honduras in the Caribbean Sea (Nicaragua v Honduras), Judgment, ICJ Reports 2007, p. 659.

${ }^{19}$ Judgment, paras. 229-33 and 238.

${ }^{20}$ Only since the Case concerning Maritime Delimitation in the Black Sea (Romania v Ukraine), Judgment, ICJ Reports 2009, p. 61, has the process been characterised as having three stages. In the cases before that, the third stage was subsumed in the second stage, giving what was described in those cases as a two-stage process.
} 


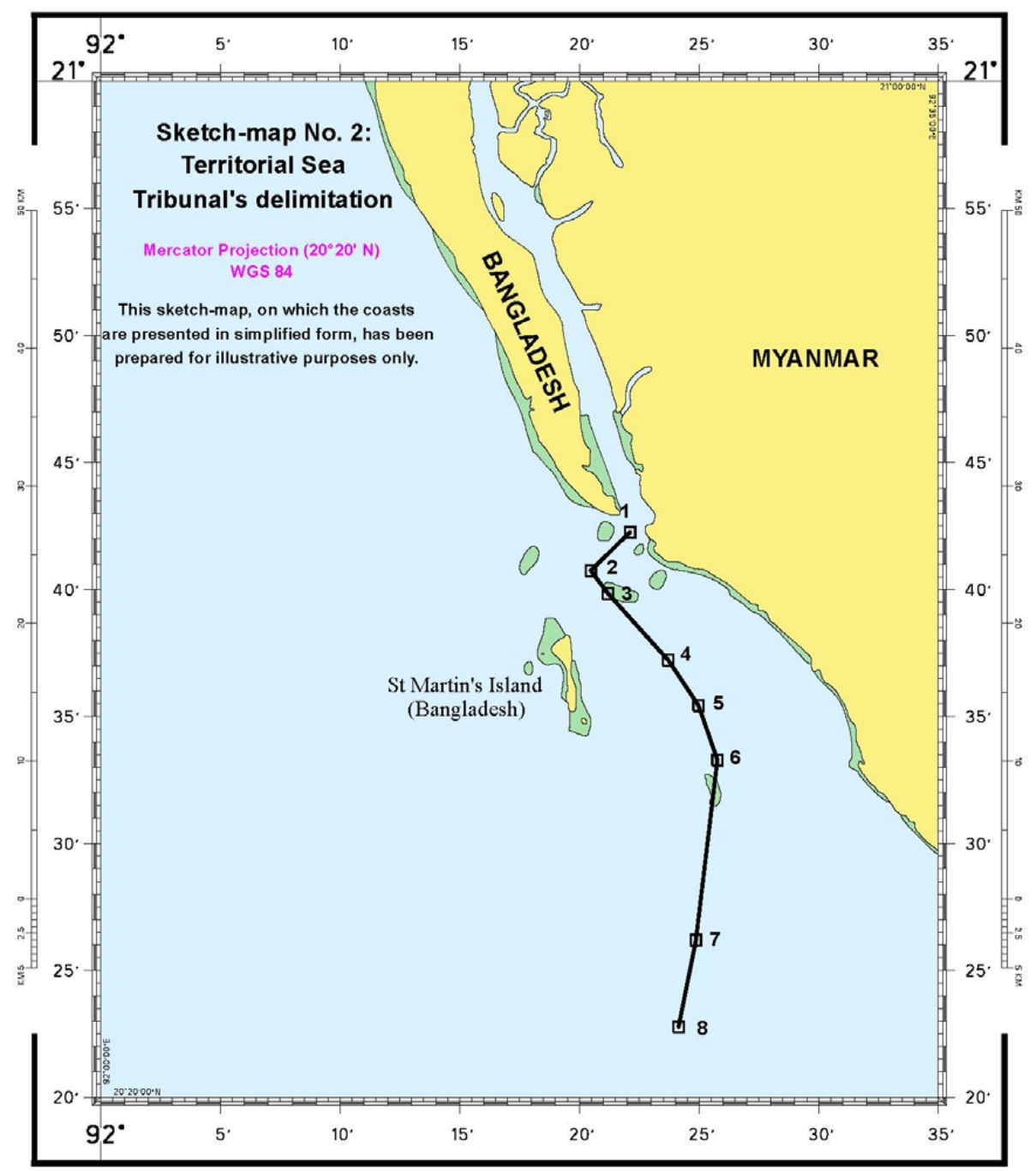

Map 1: The territorial sea boundary delimited by the ITLOS (Judgment, p. 57) 
sional boundary. It then examines that line in the light of any relevant circumstances to see whether it requires adjustment to produce an equitable result. Finally, it checks to see whether there is any significant disproportion between the areas allocated to each state as a result of the delimitation and the lengths of their respective relevant coasts. The ITLOS endorsed and used this methodology in the Bangladesh/Myanmar case. ${ }^{21}$ It did, however, recognise, as other courts have done, that there might be circumstances where the methodology would not be appropriate, ${ }^{22}$ but considered that the case before it was not such an exceptional situation, in spite of the fact that Bangladesh had argued strongly that it was and that the angle-bisector method should be used. ${ }^{23}$

In approaching the first stage and drawing an equidistance line, the ITLOS had first to select the base points for the construction of that line. The ITLOS noted that it was not obliged to follow the base points indicated by the parties but could select its own base points "on the basis of the geographical facts of the case". ${ }^{24}$ The ITLOS decided not to use St. Martin's Island as a base point because the island was located immediately in front of Myanmar's mainland coast and so its use as a base point would result in a line that blocked the seaward projection from Myanmar's coast, resulting "in an unwarranted distortion of the delimitation line". ${ }^{25}$ Instead the ITLOS chose two base points on Bangladesh's coast and four on the coast of Myanmar. ${ }^{26}$ Beginning from a point midway in the mouth of the Naaf River, the ITLOS then constructed an equidistance line using its selected base points. ${ }^{27}$

The second stage was for the ITLOS to consider whether there were any relevant circumstances that would require an adjustment of the equidistance

\footnotetext{
${ }^{21}$ Judgment, paras. 239-40.

${ }^{22}$ Judgment, para. 235.

${ }^{23}$ The angle-bisector method is where the maritime boundary is drawn as the line bisecting the angle formed by the general direction of the coasts of the two states involved at the terminus of the land border. It is described by the ITLOS as "in effect an approximation of the equidistance method" (Judgment, para. 234). It was used in the Nicaragua/Honduras case (supra note 18) and some pre-1993 cases. See further the Judgment in the present case, paras. 213-17, 220 and 234-7.

${ }^{24}$ Judgment, para. 264. This approach, which follows that of courts and tribunals in earlier cases, meant that the ITLOS did not have to consider the validity of Bangladesh's controversial straight baseline system, whose base points are all located in the sea, most on the 10-fathom isobath. See further R. R. Churchill and A. V. Lowe, The Law of the Sea (Manchester University Press, 1999), at 40 and Shah Alam and Al Faruque, supra note 4, at 411-12.

${ }^{25}$ Judgment, para. 265. However, as will be seen below, St. Martin's Island was not totally ignored in delimiting the boundary.

${ }^{26}$ Judgment, para. 266.

${ }^{27}$ The line is portrayed in the Judgment, at 86.
} 
line. Myanmar had argued that there were no such circumstances, Bangladesh that there were three-the concave shape of its coastline, St. Martin's Island and the Bengal depositional system. As to the first of these, the ITLOS observed that in the delimitation of EEZ and continental shelf boundaries:

[C]oncavity per se is not necessarily a relevant circumstance. However, when an equidistance line drawn between two States produces a cut-off effect on the maritime entitlement of one of those States, as a result of the concavity of the coast, then an adjustment of that line may be necessary in order to reach an equitable result. ${ }^{28}$

That was the situation here. As to St. Martin's Island, the ITLOS, while accepting that in principle islands could be considered to be relevant circumstances depending on "on the geographic realities and the circumstances of the specific case", ${ }^{29}$ held that St. Martin's Island was not a relevant circumstance in this case for the same reason that it was not used as a base point in constructing the equidistance line. ${ }^{30}$ This seems a little confusing as it suggests that islands are a factor to be taken into account both in constructing the equidistance line as the provisional boundary and as a relevant circumstance for adjusting that line. One might have thought that they would be considered for only one of those exercises. Bangladesh's third suggested relevant circumstance, the Bengal depositional system, was summarily rejected by the ITLOS on the basis that a single maritime boundary within 200 miles was to be determined "on the basis of geography of the coasts of the Parties in relation to each other and not on the geology or geomorphology of the seabed of the delimitation area" ${ }^{31}$ When it came to adjusting the line to take account of the concavity of Bangladesh's coast, it was noted that there was no single solution that was mandated but that various adjustments could be made that would produce an equitable result. ${ }^{32}$ It decided that the adjustment would begin at point 11 shown on map 2, "where the equidistance line begins to cut off the southward projection of the coast of Bangladesh". ${ }^{33}$ From this point the ITLOS decided, in a passage that is rather laconic in its reasoning, that the boundary should be the azimuth

\footnotetext{
${ }^{28}$ Judgment, para. 292.

${ }^{29}$ Judgment, para. 317.

${ }^{30}$ Judgment, para. 318.

${ }^{31}$ Judgment, para. 322.

32 Judgment, para. 327.

${ }^{33}$ Judgment, para. 331.
} 
of $215^{\circ}$ (which, as it happens, is the same as the angle-bisector proposed by Bangladesh as the boundary), since this would cut off the seaward projection of the coasts of neither Bangladesh nor Myanmar. ${ }^{34}$ This boundary line would continue until it reached a point that was located 200 miles from "the baselines from which the breadth of the territorial sea of Bangladesh is measured". ${ }^{35}$ The ITLOS decided that the single maritime boundary would commence where the outer limit of the 12-mile territorial sea around St. Martin's Island intersected with the equidistance line drawn by the ITLOS. ${ }^{36}$ Thus, the island was given a full 12-mile territorial sea at the expense of a small part of Myanmar's EEZ and continental shelf, and so turned out not to be wholly irrelevant to the construction of the single maritime boundary.

The ITLOS deferred carrying out the third stage of delimiting the single maritime boundary, the proportionality test (or, as the ITLOS dubbed it, the "disproportionality test") ${ }^{37}$ until after it had delimited the boundary of the continental shelf beyond 200 miles. This test involves comparing the ratio of the areas accruing to each party from the provisional delimitation resulting from the first two stages of the process with the ratio of their respective relevant coasts. The areas accruing to each party are those areas located within the "relevant area", namely "the area of overlapping entitlements of the Parties that is relevant to this delimitation". ${ }^{38}$ From the language of the judgment it is not clear whether the "relevant area" was limited to the area within 200 miles or included areas beyond, but the map of the relevant area on page 144 of the judgment clearly includes areas beyond 200 miles. One question was what account should be taken of the fact that the size of the area accruing to Bangladesh could be affected by the location of its eventual boundary with India. On this point the ITLOS decided simply that "the fact that a third party may claim the same maritime area does not prevent its inclusion in the relevant maritime area for the purposes of the disproportionality test". 39 The ITLOS determined that the "relevant area" was $283,471 \mathrm{~km}^{2}$. This is considerably larger than any of the four figures suggested by the parties as the size of the relevant area. It is perhaps just as well that determining the size of the relevant area is

\footnotetext{
${ }^{34}$ Judgment, para. 334-5.

${ }^{35}$ Judgment, para. 340 . As will be seen below, this point is less than 200 miles from the baselines of Myanmar. One must assume that the reference to "baselines" here is not to Bangladesh's controversial straight baseline system (see supra note 24).

${ }^{36}$ Judgment, para. 337; and see also paras. 168-9.

${ }^{37}$ Judgment, para. 477.

${ }^{38}$ Ibid.

${ }^{39}$ Judgment, para. 494.
} 
not, according to the ITLOS, an exercise requiring "mathematical precision". 40 Be that as it may, the ITLOS found that the relevant area was divided between the parties in the ratio of 1:1.54 in favour of Myanmar, ${ }^{41}$ and that the ratio of the relevant coasts of the parties was 1:1.42, also in favour of Myanmar. ${ }^{42}$ Thus, there was no "significant disproportion in the allocation of maritime area to the parties relative to the respective lengths of their coasts that would require the shifting of the adjusted equidistance line in order to ensure an equitable solution" ${ }^{43}$

\section{The continental shelf boundary beyond 200 miles}

The first issue for the ITLOS was whether it had jurisdiction to delimit the continental shelf boundary beyond 200 miles, and if it did, whether it was appropriate to exercise that jurisdiction. The ITLOS dealt fairly briefly with the first point, simply noting that because there was in law only a single continental shelf, whether within 200 miles or beyond, its jurisdiction to delimit the continental shelf applied to the shelf in its entirety. ${ }^{44}$ However, the question of whether it should exercise that jurisdiction was much less straightforward. UNCLOS provides that a state's continental shelf may extend beyond 200 miles if certain geological and geomorphological criteria set out in Article 76 are fulfilled. A state that considers that its continental shelf extends beyond 200 miles must make a submission setting out its view as to the outer limit of its shelf to the Commission on the Limits of the Continental Shelf (CLCS), a body of independent experts in geology, geophysics and hydrography established by UNCLOS. The CLCS is to make recommendations to the coastal state regarding its submission. The outer limit of the shelf established on the basis of those recommendations is final and binding. ${ }^{45}$ UNCLOS is less than clear on the relationship between the establishment of the outer limit of the continental shelf according to the procedure just described and the delimitation of the boundary between overlapping continental shelves beyond 200 miles. Article 76(10) states that the provisions of the preceding paragraphs of the article

\footnotetext{
${ }^{40}$ Judgment, para. 477.

${ }^{41}$ Judgment, para. 499.

${ }^{42}$ Judgment, para. 498. See also paras. 185-205.

${ }^{43}$ Judgment, para. 499.

${ }^{44}$ Judgment, paras. 360-3.

${ }^{45}$ Art. 76(8) and Ann. II, UNCLOS.
} 


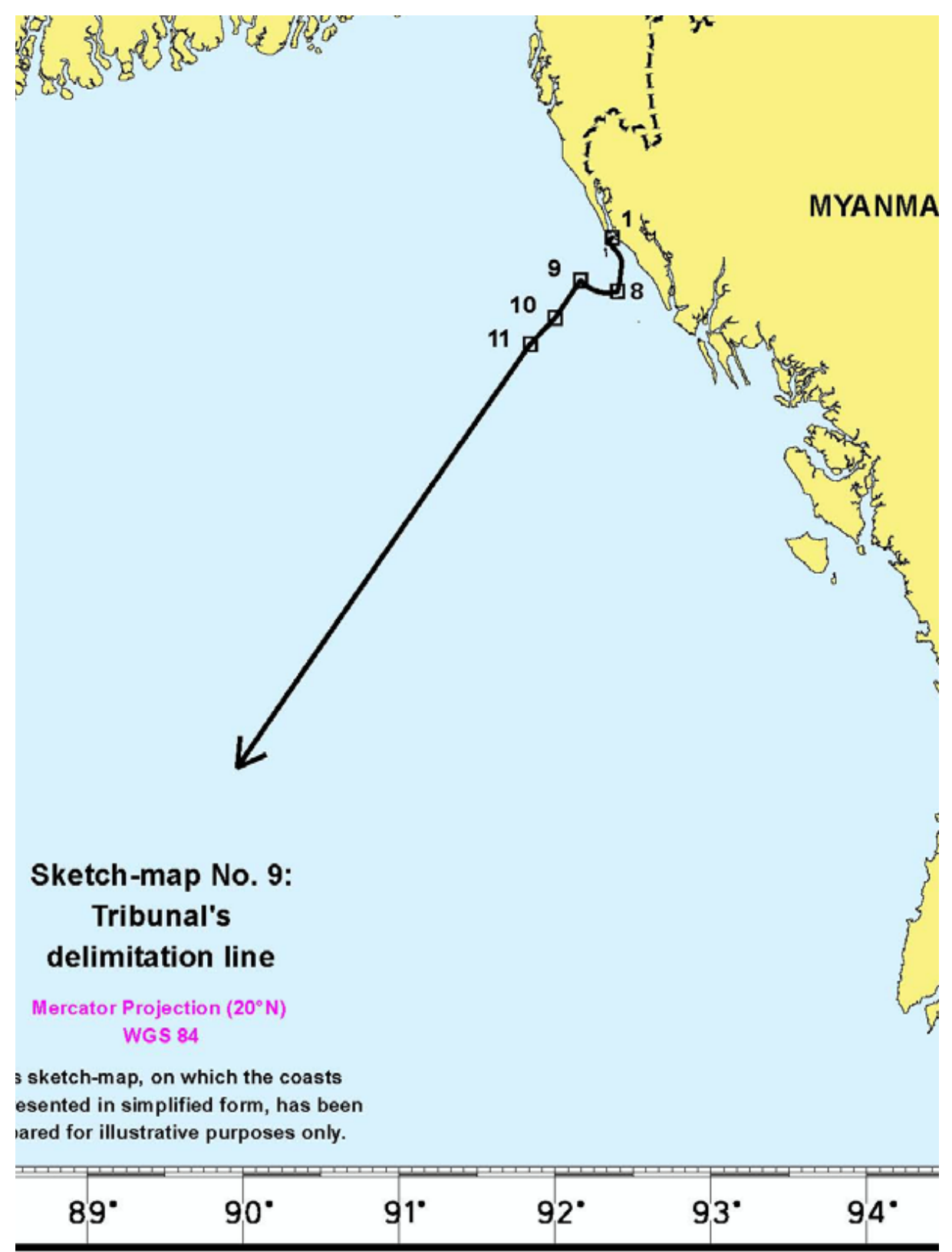

Map 2: The single maritime boundary delimited by the ITLOS (Judgment, p. 146.) 
are "without prejudice to the question of delimitation of the continental shelf between states with opposite and adjacent coasts". Likewise, Article 9 of Annex II provides that the actions of the CLCS "shall not prejudice matters relating to the delimitation of boundaries between states with opposite and adjacent coasts". The Rules of Procedure of the CLCS provide that the CLCS shall not consider submissions relating to an area where there is a dispute unless both/all parties to such a dispute give their consent. ${ }^{46}$ Both Bangladesh and Myanmar have made submissions to the CLCS. Bangladesh has not given its consent to consideration of Myanmar's submission by the CLCS. ${ }^{47}$

In the past international courts and tribunals have taken different views as to whether they may delimit the continental shelf beyond 200 miles in areas where the CLCS has not made a recommendation to the coastal states concerned. In the Canada/France and Nicaragua/Honduras cases the arbitral tribunal and ICJ, respectively, took the view that they could not delimit the continental shelf boundary beyond 200 miles; ${ }^{48}$ whereas in the Barbados/Trinidad and Tobago case the arbitral tribunal decided that it could (although in practice it did not do so as there were no overlapping continental shelves beyond 200 miles). ${ }^{49}$ In the present case the ITLOS decided that it was competent to, and should, delimit the continental shelf beyond 200 miles. It pointed out that such delimitation would not impede the CLCS in carrying out its functions, ${ }^{50}$ and that without delimitation, the establishment of the outer limits of the continental shelves of Bangladesh and Myanmar might remain unresolved, given the lack of consent by the two states to the CLCS considering the matter. ${ }^{51}$

Before delimiting the boundary, the ITLOS had first to assure itself that the parties had overlapping entitlements to the continental shelf beyond 200 miles, otherwise there was no boundary to determine. It rejected Bangladesh's argument that natural prolongation was the primary criterion in establishing an entitlement to a continental shelf beyond 200 miles and that consequently Myanmar had no such entitlement because of a fundamental discontinuity

\footnotetext{
${ }^{46}$ Para. 5(a), Ann. I, Rules of Procedure, CLCS available at $<$ http://daccess-dds-ny.un.org/doc/ UNDOC/GEN/N08/309/23/PDF/N0830923.pdf?OpenElement> [last accessed 22 April 2012].

${ }^{47}$ Judgment, paras. 387-9.

${ }^{48}$ Case concerning Delimitation of Maritime Areas between Canada and France, (1992) 31 ILM 1145, at 1171-2, paras. 75-82; and Nicaragua/Honduras case, supra note 18, at 759, para. 319.

${ }^{49}$ Arbitration between Barbados and Trinidad and Tobago, RIAA, Vol. XXVII 147, at 209, paras. 217, 242 and 368.

${ }^{50}$ Judgment, paras. 378-90 and 393.

${ }^{51}$ Judgment, paras. 390-2.
} 
between Myanmar's landmass and the seabed of the Bay of Bengal beyond 200 miles. Instead, the ITLOS held that entitlement to a continental shelf depended primarily on satisfying the criteria of Article 76(4) of UNCLOS. ${ }^{52}$ It noted that the floor of the Bay of Bengal was covered by a thick layer of sediment some 14-22 km deep. Thus each state could claim a continental shelf beyond 200 miles based on the thickness of sedimentary rocks criterion in Article 76(4)(a)(i). The origin of such sediments (the Himalayas and Tibetan plateau) was irrelevant. ${ }^{53}$ It was also clear that those entitlements overlapped. ${ }^{54}$ As to how those entitlements should be delimited (an issue never previously considered by an international court), the ITLOS observed that Article 83 of UNCLOS (on delimitation of the continental shelf) does not distinguish between delimitation within 200 miles and delimitation beyond 200 miles. Thus, "the delimitation method to be employed in the present case for the continental shelf beyond 200 nautical miles should not differ from that within $200 \mathrm{~nm}$. Accordingly, the equidistance/relevant circumstances method continues to apply for the delimitation of the continental shelf beyond 200 nm. ${ }^{55}$ This view appears to take no account of the fact that the delimitation undertaken by the ITLOS within 200 miles was not solely of the continental shelf but was a single maritime boundary for both the continental shelf and the EEZ. As a consequence of its view, the ITLOS had little hesitation in rejecting Bangladesh's arguments that geological and geomorphological factors were relevant. On the other hand, the concavity of Bangladesh's coastline continued to be a relevant circumstance. The ITLOS therefore decided that the boundary between the parties' overlapping continental shelves beyond 200 miles should be a continuation of the single maritime boundary line until it reached the area where the rights of third States (i.e. India) might be affected. ${ }^{56}$

The ITLOS would appear to have been justified in delimiting the continental shelf beyond 200 miles in this case. Given the unique geological characteristics of the Bay of Bengal, there seems little doubt that Bangladesh and Myanmar both have entitlements to a continental shelf beyond 200 miles that overlap. However, in future cases it may be advisable for an international court to proceed more cautiously in deciding whether to delimit a continental shelf boundary beyond 200 miles. It may not be obvious that the states concerned have entitlements to a continental shelf beyond 200 miles and that such enti-

\footnotetext{
${ }^{52}$ Judgment, para. 437.

${ }^{53}$ Judgment, para. 444-8.

${ }^{54}$ Judgment, para. 449.

${ }^{55}$ Judgment, para. 455.

${ }^{56}$ Judgment, para. 462.
} 
tlements overlap. To determine such matters may involve a court in having to make judgments about complex geological and geomorphological facts which it is ill-equipped to do. If a court does refrain from delimiting a continental shelf boundary, that may mean that the CLCS will not be able to consider the submissions of the states concerned because of a lack of consent. If that situation is not to turn into a "jurisdictional black hole", as Bangladesh memorably characterised it, ${ }^{57}$ the parties will have to redouble their efforts to remove the impasse by diplomatic means. In the present case, however, the judgment of the ITLOS has resolved the impasse before the CLCS. Since there is no longer a dispute between Bangladesh and Myanmar, the CLCS can now go ahead and consider the submissions of each state.

As regards the methodology of the delimitation, the decision of the ITLOS to exclude geological and geomorphological factors as relevant to the determination of the boundary line would seem to be correct in this case. Once the ITLOS had decided that the origin of the sediments in the Bay of Bengal was irrelevant-which was surely right, otherwise Nepal and China might have as much claim to the seabed of the Bay of Bengal as the riparian states-and, perhaps arguably, that natural prolongation was not relevant, the geological and geomorphological factors at issue appear to apply equally to Bangladesh and Myanmar. However, the decision of the ITLOS in this case does not mean that in future cases geological and geomorphological factors may not be relevant circumstances that should be taken into account in delimiting a continental shelf boundary beyond 200 miles. The primary reason for excluding such factors when delimiting a single maritime boundary is because they have no relevance to the water column that is also being delimited. ${ }^{58}$ That rationale does not apply beyond 200 miles.

\section{The grey zone issue}

A grey zone (or "grey area", as it is referred to in the judgment) in the context of maritime boundary delimitation refers to the situation where an area on one side of a maritime boundary is beyond 200 miles from the state on the same side of the boundary but within 200 miles of the state on the other side of the boundary. Grey zones are liable to occur whenever a single maritime boundary is not an equidistance line, and especially where such a line is extended to form

\footnotetext{
${ }^{57}$ Judgment, para. 358.

${ }^{58}$ Delimitation of the Maritime Boundary in the Gulf of Maine Area (Canada/USA), Judgment, ICJ Reports 1984, p. 246, at 326-7, paras. 192-5.
} 
the boundary of the continental shelf beyond 200 miles. The result of the delimitation of the boundary by ITLOS in this case was to create a grey zone on Bangladesh's side of the boundary. ${ }^{59}$ The ITLOS noted that the boundary abutting the grey zone delimited the continental shelf only (since the EEZs of the parties in this area did not overlap), but did not "otherwise limit Myanmar's rights with respect to" the EEZ, notably as regards the superjacent waters. ${ }^{60}$ Thus, the seabed of the grey zone is Bangladesh's continental shelf and the superjacent waters Myanmar's EEZ. It is up to each state, acting in accordance with UNCLOS (especially Articles 56, 58, 78 and 79) to "exercise its rights and perform its duties with due regard to the rights and duties of the other" ${ }^{61}$ This is the first occasion on which an international court has pronounced on the status of grey zones. What the ITLOS says is therefore important. The logic of its position seems difficult to question, although it may pose challenges to states to act with the necessary due regard when exercising their rights in a grey zone.

\section{Conclusions}

Although this was its first case concerned with delimiting a maritime boundary, the ITLOS showed itself to be a competent tribunal for this purpose. In spite of its potentially unwieldy size, with 22 judges sitting in the case, the ITLOS managed to maintain an impressive degree of unity. Of the six points voted on in the operative paragraph of the judgment, the smallest majority was 19-3: on half the points the majority was 21-1. Notable is the fact that the two ad hoc judges voted with the majority on all points and made a joint declaration. The judgment was delivered with commendable speed, in two years and three months after referral. That is comparable to the time taken by the three most recent arbitral tribunals and substantially quicker than the ICJ. Compared with arbitration, the ITLOS is cheaper because the parties are not required to pay the costs of the arbitrators, the registrar or the hire of premises.

This case may therefore encourage states parties to UNCLOS wishing to litigate maritime boundary disputes to consider using the ITLOS for this purpose, especially since the ITLOS followed the now well-established case law (from which it quoted copiously) on the delimitation of single maritime boundaries. ${ }^{62}$

\footnotetext{
${ }^{59}$ Portrayed in the map at 138 of the Judgment.

${ }^{60}$ Judgment, paras. 471 and 474 .

${ }^{61}$ Judgment, para. 475.

${ }^{62}$ A very different view is expressed by Judge Gao in his Separate Opinion, however. He considered that the ITLOS had definitely not followed the existing case law: see para. 53
} 
Thus, fears that involving yet another tribunal in maritime boundary delimitation risks fragmenting the international jurisprudence should have been allayed by this case. The novel points in the case-delimitation of the continental shelf beyond 200 miles and the legal status of the grey zone - were dealt with by the ITLOS in a reasonable and equitable manner. As suggested above, the approach of the ITLOS to delimiting the continental shelf beyond 200 miles seems justifiable in the particular circumstances of this case, but may not be so in future cases. In spite of its considerable length (506 numbered paragraphs), there are places where the judgment would have benefitted from fuller reasoning. However, that criticism may also be made of a number of previous maritime boundary delimitation cases.

of his Separate Opinion. Although Judge Gao voted with the majority on the course of the single maritime boundary within 200 miles, he profoundly disagreed with the methodology employed by the ITLOS and thought that the angle-bisector method should have been used instead. 